\title{
Paradigm Shift in Knowledge Creation through Higher Education
}

\author{
Vinita M. Chaudhary1, Dr. Shashi Malik2 \\ 1(Research Scholar, Education Department, VMLG College C.C.S University, Meerut) \\ 2(Guide, Education Department, VMLG College C.C.S University, Meerut)
}

\begin{abstract}
Higher education systems have changed all over the world, but not all have changed in the similar ways. Even though system expansion and massification have been universal themes, there have been systemspecific changes as well. It is these changes that have an important impact on academic work and on the opinions of the staff that work as higher educators. The academic profession has a key role to play in producing the next generations of knowledge workers, and this task will be more readily achieved by a relaxed academic staff working within well-resourced teaching and research institutions. Teachers are human soul, emotionally concerned with several personal and family oriented requirements to be met. Unable to complete those requirements may result in frustration, isolated behavior, and finally they get dismayed. Unluckily, in the present situation, the teacher is especially a fatality of such malicious circumstances. The rationale of the study is to ascertain the relationship between challenges of higher education and satisfaction of their teachers. Academically the study will provide obligatory knowledge for the future researchers to base on as means of reference.
\end{abstract}

Keywords - Aided colleges, Higher education, Job Satisfaction, Privatization, Teachers

\section{INTRODUCTION}

In India, we have a prosperous cultural inheritance for education. India has always been and is still today a wide-ranging society in the sense that a very wide variety of cultural and religious beliefs exist side by side. The earliest recorded system of education is found in Rig Veda. Veda means" to know and it generally deals with the philosophy of life and the practices in knowledge. The time is called the Vedic Era and is thought to be almost 5000 years old. During this period education revolved around the structure of Gurukuls. It was inclusive education in the truest sense. Students found unable of academic learning were given options to learn other occupations, which they could do easily, such as tending cattle, farming or housework. This was precisely seen as an opportunity to be suitably employed and was not thought insulting but prevented the hierarchy of the educated and the uneducated. This noteworthy milestone, providing education for persons, was based around the 1st century B.C. According to a legend tale, a king has three "dull witted" sons, he began a countrywide hunt for someone who would be able to teach his dull witted sons. Visnusarman a noble guaranteed the king that he would invent special ways of teaching the royal pupils. He developed his strategy for education using a compilation of animal fables, which educated the princes matters related to diplomacy and ethics honored universally. This resulted in "The Panchatantra", the most primitive Indian collection of animal fables from around $1000 \mathrm{BC}$, and is perhaps the first book on exceptional education. Even today, in India, small rural schools provide education for all children under one roof. The awful fact seems to be that somewhere on our way towards modernization we have lost this unique system of education.

The Vedic Period was followed by an era when Brahmanic influences took slow but sure control and the unfortunate caste system took root. The extend of the caste system introduced unhealthful attitudes and practices and was at least in part the cause for the reforms preached by Gautama Buddha. Buddhist philosophy and Buddha's teachings influenced the education system giving rise to Viharas or Muths and became the centers of learning replacing the Gurukuls.

In712 A.D. when an Arab Mohamed Bin Kasim invaded India, he brought with him the Muslim influence and this can be seen as the commencement of the Muslim Period. Many Madarsas (schools) and Maktabs (attached to Mosques) were established, principally to teach the religion of Islam but bit by bit replaced the ancient Indian institutions of learning.

During the period of the Mughal empire, which followed the Muslim period, education made great progress since most of the kings and in particular Akbar the great saw education as secular and were committed to the cause of education. When the Mughal Empire began to collapse, weak political administration gave way to anarchism.

During the period of instability, The British who first came to India for trade established the East India Company, but soon exploited the existing political situation to set up themselves firmly as rulers. The British introduced a scheme to provide education to the Indian cream of the crop only called "downward filtration". Credit of introducing for the first time a well planned and graded system of education must go to 
Charles Wood, the Chairman of the Board of Control of the East India Company, who in 1854 made numerous recommendations (known as Woods Dispatch) resulting in the first ever educational policy in the interests of India, which became an integral part of the general policy of the Indian government. With the transfer of power from the East India Company in 1857 to the British, a Commission of Education was set up under William Hunter in 1882 (known as Hunter Commission) and was the first ever commission to look into education in the country as national policy.

When India became free of the British colonizers in 1947, the government began to become formally concerned in policy decisions at a national level. In 1953 the Central Social Welfare Board, in 1974 the National Policy for Children and The Integrated Child Development Program (ICDS) as a part of India's Fifth five year plan were formed. The Ministry of Education system by the British was later divided into the Ministry of Social Justice and Empowerment and the Ministry of Human Resource Development. The Ministry of Social Justice and Empowerment provides support through grant in aid schemes to unpaid or charitable organizations and these could cover education if applied for. After independence, consecutive government have tried to address the limitations of the Indian education system in the frame work of its constitution and have introduced various policies and programs for widening admittance to education and for enhancing the literacy and quality of education at all levels in the country. Thus the structure of the present day Indian education system is based on assorted stages of learning: as Nursery, Primary, High school, Secondary education and Higher education.

\section{HighER EDUCATION}

"Education is the most powerful weapon which you can use to change the world". The above mentioned line by Nelson Mandela exemplifies that education plays an essential role in the advancement of fate of individuals as well as their society and finally escort to a nation's development. When there was no university anywhere in Europe, Takshasila, Vikramasila, Pallavi and Nalanda vishvavidyalayas in India were radiating the heat of higher learning and were able to catch the attention of learners from home and abroad. Bengal had a particular role in the expansion of the possibility of higher education, and the development of modern higher education in India started with the establishment of Hindu College in Calcutta in 1817. In the whole of the then British empire, Calcutta University was the first to confer the bachelor degree on women in 1883; Kadambini Ganguly and Chandramukhi Basu were the first recipients of this honor.

The University Grants Commission (UGC) which came into existence on 28th December, 1953, became a constitutional organization by an Act of Parliament in 1956. It is a national body for the synchronization, determination and maintenance of standards of University education. It serves as a coordinating body between the Union and State Governments and the institutions of higher learning. It also acts as an advisory body to these Governments and institutions on issues relating to higher education. To complete the objective of higher education Government must contribute to the initiation and strengthening the process of development with the equity, justice, solidarity and autonomy as the key rudiments, the nucleus mission of higher education " to educate, to train, to undertake research and to provide services to the community" must be preserved and reinforced and further extended. This requires that higher education enjoy independence and liberty exercised with responsibility. The healthy growth of any nation requires educated populace with skills and expertise in all disciplines in all subjects both at basic and professional levels with equal emphasis and importance. The Tenth Plan provides the foundation for higher education in the 21st century. Keeping in line with the changing and promising scenario of higher education due to globalization and liberalization of economies, the UGC has initiated and being implemented about 70 new schemes, broadly categorized into five sectors viz. (i) General Development of Universities (ii) Enhancing Access and Equity (iii) Promotion of Relevant Education (iv) Quality and Excellence (v) Strengthening of Research to meet the objectives of the Tenth Plan. The university system plays an important role in creation of new knowledge. Earlier knowledge produced in universities used to be in public domain. Now that knowledge is the new currency of economic power. It is the source of prime competitive improvement; universities enthusiastically guard their knowledge base. The economic returns from protected knowledge motivates new knowledge creation and therefore fuels innovation [1].

This is a paradigm shift in knowledge creation through universities. Tendency world over is to protect new knowledge as intellectual assets with private possession. Promoting Indian Education overseas is regarded as a strategy to promote quality of our education by the UGC, as a means of creating multi-cultural ambience on Indian campuses that promotes diversity and international goodwill. With the cost benefit in our favor, there is a distinct prospect of getting larger number of international students to India. This would require positioning of Indian Higher Education as a discrete brand, accurate stratagem and action plan [2].

Education is the first and primary human right as proclaimed in Article 26 of Universal Declaration of Human Rights. It not only makes man flexible to change and adjust with the new situations but acts as the key to building up the skills and capacities in all domains compulsory for techno-economic expansion. In the world of 
tomorrow, education should not only be concerned with simple transmission of knowledge but must promote all forms of behavior, life styles, and values necessary for human survival on a jam-packed planet.

\section{REORIENTATION OF Higher EdUCATION IN A NEW-FANGLED ERA}

The new challenge before the country at the beginning of the twenty first century is to become a developed society by the year 2020, which requires that not only an energetic economy motivated by knowledge has to be ushered in next to no time, but also a new society where justice and human values overcome has to be created. Moreover, challenges in higher education are no longer only nation centric. They have already attained global dimensions, generally after trade in services has been brought under the purview of the WTO system.

With the volatile growth of knowledge in the past century and with the development of versatile tools of information and communication technologies as well as of other scientific innovations, competition has become a trademark of growth all over the World. As a result, knowledge is not only going to be the driver of Indian economy, but also, it is going to percolate into all the stratum of Indian society for a better quality of life and living conditions. Consequently, India has to rise to the occasion urgently and reorient its higher education system to be vibrant, competitive, significant and focused; more to the point, there is absolutely no replacement to quality of higher education, although the country has been faced for a long time with the serious dilemma of meeting the quantity and quality requirements of our society. It is, therefore, necessary that a careful balancing of the two is given priority to meet the twin requirements of the society in the expected future.

The higher education has become the need of the hour for populace to keep themselves in equivalence with the global arena and fast developing economy. These changes make new demands and pose fresh challenges to the conventional education systems and practices in the country. Because of interdependence and amalgamation of world economy in recent years, the Indian higher education system has a new role and a challenge to provide to the nation and the world, at large skilled human power at all levels, having breadth of knowledge and confidence to effectively confront the social and economic realities.

Thus higher education has become vital to every individual to modernize his knowledge according to requirements of this swift development. Educational opportunities and ethnicity that Indian Universities have built up, since independence have been able to careers, but, in the new globally competitive environment that is emerging in the country, the Indian student is now required to develop a versatile personality to cope up with the speedy changes in the world at large. This calls for the development of body, mind and spirit, through the educational processes in the institutions of higher education. The idea of allowing students to do Diploma or Certificate courses alongside with their Degrees, recently put onward by the UGC, is a welcome step towards empowering the students to occupy work soon after their Degree courses. There shall be a system to accredit these courses and facilities to ensure quality. This is an area where public/private partnership has a creative role to play. The Gross Enrollment Ratio (GER) in India continues to significantly trail its global peers and the world standard, intimidating the constant high growth of the Indian economic engine. The government has therefore set a Target of $30 \%$ GER by 2020, which seems difficult to achieve at the current pace of expansion. Furthermore, the Indian higher education system faces the challenges of ensuring equity and quality. The private higher education sector in countries such as the Unites States, Japan, and Malaysia has been instrumental in tackling these challenges. In India as well, the private segment could play a key role in dealing with these issues through innovative models supported by an enabling authoritarian structure and surroundings. Up till then, the private sector has played an important role in the development of the higher education sector, especially in professional disciplines such as engineering and management. High potential claim for higher education and inadequate government expenditure on capacity creation are expected to result in a substantial infrastructure and investment discrepancy. In this backdrop, the role of the private sector has assumed increased significance with gigantic opportunity for private sector players.

\section{Public/Private Partnership}

The practice of privatization began to materialize in the late 1900's, as Indian higher education system has undergone immense expansion in post-independent India with a national resolution to establish several Universities, Technical Institutes, Research Institutions and Professional / Non-professional Colleges all over the country, to generate and propagate knowledge coupled with the splendid intention of providing easy access to higher education to the common Indian. The civic initiatives played a leading and controlling role in this segment. Most of the Universities were Public institutions with powers to adjust academic activities on their campuses as well as in their areas of jurisdiction through the affiliating system. Even the private institutions enjoyed extensive financial support in the form of grants from the public exchequer. Private funds as well as individuals played key roles in the grounds of higher education.

Private educational institutions in India could be classified into the following categories: 
Aided Colleges: Aided colleges are privately managed but they are funded by the government. Section 3(b) of the Private professional educational institutions bill, 2005 defines an 'aided institution' as a private professional educational institution, receiving financial aid in whole or in part from the government.

Unaided Colleges: Unaided colleges are privately managed and raise their own funds. These are called self financing colleges. The Honorable Supreme Court has announced that the right to admit students being an essential fact of the right to administer educational institutions of their choice (Article 30 of the constitution).

With the public funding being no more in a situation to take-up the challenging mission of expansion and diversification of the higher education system in the country to meet the continuously growing demands at present, there is little alternative other than bringing in private initiatives in a mammoth way to meet the diverse challenges. The deregulating machine of controls started with the granting of "Autonomous Status" to identified Colleges in the 1970s, Some of these Colleges have graduated further to take delivery of the "Deemed to be University" status in later years. Now, the country is on the doorstep of the establishment of Private Universities in different States. Across-the-board, the private sector has played a key task in addressing these challenges. In India, the private sector has, till now been influential in increasing infiltration and enrollment, especially in professional disciplines. The contribution of unaided private institutions in the higher education sector has increased noticeably over the last few years. Majority of institutions offering programmes in professional disciplines such as engineering, pharmacy, and hotel management have been established by the private sector. As of 2006-07, private sector involvement ranged from 50\% to $95 \%$ of the total number of institutions for different professional courses.

The self financing institutions usually run professional courses, viz, Engineering, Pharmacy, Hotel management, Architecture, Teacher education, Computer technology, Human resource management, Medicines and Physiotherapy etc. Here in (figure1) graphical representation of the data regarding number of public and private institutions in different professional courses is presented, which shows there are more private colleges than public colleges in professional courses. This higher number of self-financing institutions shows growth of privatization in higher education in different professional courses.

100
80
60
40
20
0

Fig. 1 Relative share of Private and Public institutions for professional courses

There has also been a brisk growth in the percentage of students enrolled in unaided private higher education institutions. The consequent widening of the demand supply gap will result in an infrastructure and investment discrepancy, creating expansion and admission opportunities for private sector players. These and associated issues figured notably, are as follows:

1. For any higher education institution aspirant for quality is Good Faculty. This could assure continuous infusion of young blood in to the teaching cadre; which is not happening at the moment. With some restrictions on faculty appointments, the present malevolence of inbreeding can be eliminated. The inbreeding has ruined many departments at Universities.

2. Those who shall endeavor investment in this area properly scrutinized and if commercial interests dominating over the wellbeing and ethics of higher education shall be eliminated. Private Universities are a truth now and, as such, strong regulatory mechanisms are to be put in place without delay to monitor and control their activities with the objective of ensuring quality and social responsibility. Higher education is a Public Good and cannot be left to the market forces to manage [3].

3. For a healthy Public/Private partnership by way of exchanging good practices a thorough reform can do much. A leading management system, lean but professional, making use of contemporary communication and information technologies is required to facilitate quality higher education. There shall be a dominant role for 
authentic academics in the governing structure of higher education institutions. It needs practice to the present outmoded administrative.

4. To make sure the quality and standard of the teachers at higher educational institutions the appraisal has to be continuous and the process has to be transparent to gain the acceptance of the society at large. The regulatory mechanism shall have instruments to ensure that accessibility and quality up gradation are inseparable dimensions of higher education. Over-emphasis on one at the cost of the other would be counterproductive.

5. To get better quality of higher education the system needs to be expanded to a much greater scale to serve the needs of the Indian youth. Emphasis on quality parameters becomes all the more necessary in the light of mushrooming of private institutions with the opening up of the Indian economy.

Many institutions of higher education in the country are excellent in the sense that their infrastructure, resources, faculty, programmes of teaching and research are almost as good as the best in the advanced countries. But, the same cannot be said of the average institutions of higher education in the country. They do not come anywhere near the level of average institutions of higher education in the advanced countries. This vast gap in standards and facilities has been a cause of constant anxiety and concern to the policy planners of higher education in India. Along with the necessary and inevitable quantitative expansion of higher education, it is equally important to improve the quality of higher education. Institutions of higher education would find it difficult to meet the challenges of globalization of higher education if one fails on this front.

The Punnayya Committee (1992-93) mentioned that higher education is a fundamental determinant of our nation's economic and technological progress.

Dr. Swami Nathan Panel (1992), which was set up by the All India Council for Technical Education, also made important annotations. The Panel has put forth the suggestion of collecting educational cess.

The Birla Ambani Report (2000) makes unambiguous recommendation. "A redefinition of government role in higher education would call for a major privatization of the university education system in India".

Setting up of NAAC has sent the right and optimistic signals for generating and promoting consciousness of the vital need of quality up gradation of Colleges and Universities. The need is to recognize efficient ways and strategies to accelerate the completion of appraisal and accreditation by NAAC within a predetermined time outline. Quality up gradation is not a onetime experience. It is continuous and persistent recreation. With a vision to ensure utmost sharing of College teachers in Workshops/Seminars/Conferences and Orientation/Refresher Courses, it is optional that these events be organized during incline periods in institutional academic work (i.e. March-July). This would help the teachers to participate in these activities without disquieting the teaching almanac. The seven parameters acknowledged by NAAC for evaluating the quality of institutions, even though useful, necessitate re-examination as they give the impression to be insufficient to fully assess the quality of higher education. NAAC could move a step ahead by starting the accrediting teaching and research [4].

Education has constantly been and continues to be one of the most important needs of mankind. It helps men to educate values and apply the technical aptitude in authentic life situations. By tradition, higher education has been considered to be accountability of the state towards its society for this reason, it has been the function of state to finance higher education, however allow it substantial autonomy, at least as far as academic matters are concerned. Educational institutions have, therefore, been fundamentally governmental in character. The revolution in the nature of higher education, from elitist to egalitarian that took place in the second half of the twentieth century, placed considerable pressure on governmental resources. The state, therefore, was left with no alternative but to allow private enterprise to enter the higher education scene. Today privately sponsored higher education is moving to the core-stage of the higher education scenario in most countries.

In India, private initiatives in higher education date back to the final years of the nineteenth century. During 1990's with the gradual privatization of higher education, the budgetary provision for higher education decreased. The government is thus gratified not only to make every effort towards providing admittance to higher education to all its citizens but must also attempt and advancement the quality of higher education in India. Webster New Collegiate Dictionary (1983) describes privatization as the transfer of ownership from the public sector to the private sector and also as the withdrawal of the state from the production of goods and services [5].

\section{Challenges And OpPortunities In Private Higher EdUCATion}

At the dawn of India's independence, there were 19 universities and 591 colleges while students enrolment at the tertiary level of education was 0.2 million. After 56 years of independence now, the number of universities, deemed universities and institutions of national importance have risen to 261, the number of degree and above level general education colleges to 8,361 , the number of professional colleges to 2,340 and total enrolment to 8.8 million. This undoubtedly is an enormous advancement. Even though India claims to have the second largest higher education system in the world, in view of its infinite population it is regarded as one of the 
rearward countries in respect of education, particularly in higher education. However, expenditure on higher education, as the percentage of gross national product (GNP), had fallen from 0.98 per cent in 1980-81 to 0.35 per cent in 1994-95. The share of higher education in the union budget's total provision for education has fallen from 28.19 per cent in 1990-91 to 17.7 per cent in 2003-04. Allocation for education in the first five-year plan was 7.2 per cent of the total outlay. In the tenth five-year plan, it has further come down to 2.9 per cent. With this realization the 11th plan aims to increase the GER to $21 \%$ by the end of Twelfth plan with an interim target of $15 \%$ by 2012. Beside the Plan also recognized that the additional increase in enrolment necessarily will have to come from those regions where the enrolment is relatively low. Thus reduction of inter-regional disparities is a part the overall strategy of increasing the enrolment rate up to $15 \%$ in 11 th Plan and further up to $21 \%$ by the end of 2012. The realization of $15 \%$ target, as mentioned above, would require additional educational institutions. This is a difficult issue, which has not been empirically addressed so far [6].

There are many challenges and opportunities of privatization in higher education. Privatization provides academic and administrative sovereignty in one hand and the uncertain availability of sufficient resources in other hand [7].

Some challenges of privatization are:

- $\quad$ Maintaining and projecting legitimate ideals accessibility and impartiality.

- $\quad$ Problem of money seeking approach.

- $\quad$ Risk of international interference.

- $\quad$ Challenge to offer quality education.

- $\quad$ Decorum of teachers will be in trouble.

- Teacher retention in colleges.

- $\quad$ Create split between haves and have-nots.

Opportunities of privatization are:

- $\quad$ Enrolment rate will be greater than before.

- Vocationalization of higher education will be carried out successfully.

- Least interference of local political and bureaucratic bodies.

- $\quad$ Opportunity to introspect by institution.

- Quality of education will be ensured due to competition in colleges.

- $\quad$ More use of ICT and practical experience.

- $\quad$ Nature and quality of research effort will be taken care.

\section{CONCLUSION}

The phrase Privatization raises numerous issues in recent times:

1. How many more universities and colleges in the country will be required?

2. Would it be possible to satisfy the teachers of self-financing institutes?

3. Would the drawback of privatization outweigh its advantages?

4. Would privatization in India lead to monopolization of higher education by the private sector?

Quality of education is both a challenge and an opportunity because it depends upon teachers' proficient qualification, responsibility, satisfaction and their retention in organization. For retention in the college and responsibility feeling, teacher satisfaction is indispensable, which depends upon many institutional and other factors. It is hoped that the stakeholders of higher education all over the country, will entertain all the sincerity it deserves and become partners in creating a Higher Education System for the country, comparable to the best in the World. Therefore, it can be concluded that more opportunities will arise, as the result of privatization and it is the need of an hour.

As a result of this effusive research, job satisfaction has been linked to efficiency, motivation, malingering/sluggishness, accidents, cerebral/corporeal health, and general life satisfaction. Job satisfaction is significant because a person's attitude and beliefs may affect his or her behavior. Attitudes and beliefs may cause a person to work harder, or, the opposite may occur, and he or she may work less. Job satisfaction also affects a person's general well-being for the reason that people spend a good part of the day at work. Consequently, if a person is dissatisfied with their work, this could lead to dissatisfaction in other areas of their life [8]. A common idea of the research has been that, to some degree, the expressive state of an individual is affected by communications with their work environment. People identify themselves by their line of work, such as a doctor, lawyer or teacher. A person's individual well-being at work, thus, is a very considerable aspect of research. 


\section{REFERENCES}

[1] Emerging Issues in Higher Education Approach and Strategy of 11th Plan, UGC Report:2008

[2] UGC (2006), Annual Report: 2004-05, New Delhi.

[3] Gupta, S.P., (1987) A Study of Job Satisfaction at three levels of teaching. In M.B. Buch (ed.), Third Survey of Research in Ed, NCERT, New Delhi, PP. 809-810.

[4] National Knowledge Commission (2007), Report to the Nation 2006, New Delhi: National Knowledge Commission, Government of India.

[5] Tilak, J.B.G. (1999), "Emerging Trends and Evolving Public Policies on Privatization of Higher Education in India", in Private Prometheus: Private Higher Education and Development in the 21st Century (ed. P.G. Altbach), Greenwood Publishing, Westport, pp. 113-35

[6] NIEPA (2005), Report of the CABE Committee on Financing of Higher and Technical Education, Central Advisory Board of Education, New Delhi, June

[7] Anandakrishnan, M. (2006), "Privatization of Higher Education: Opportunities and Anomalies", Presented at, National Seminar on Privatization and Commercialization of Higher Education, New Delhi, (2 May)

[8] Judge, T. A., \& Klinger, R. (2007) Job satisfaction: Subjective well-being at work. In M. Eid, \& R. Larsen (Eds.), The science of subjective well-being (pp. 393-413). New York, NY: Guilford Publications. 